\section{Responses of Aster, Dusty Miller, and Petunia Seedlings to Daily Exposure to Mechanical Stress}

\author{
Janne Autio, Irma Voipio, and Taina Koivunen \\ Department of Plant Production, P.O. Box 27, 00014 University of Helsinki, \\ Finland
}

Additional index words. brushing, burlap, Callistephus chinensis, Petunia, Senecio bicolor, thigmomorphogenesis

\begin{abstract}
Seedlings of aster [Callistephus chinensis (L.) Nees], dusty miller [Senecio bicolor (Willd.) Tod.], and petunia (Petunia Juss.) were subjected to brushing with burlap in two experiments. The spring experiment tested the daily duration of brushing $(60,120$, or 180 minutes per day) and the autumn experiment tested the stimulus of brushing (brushing for 2 hours with single-layer, double-layer, or triple-layer burlap). Brushing was done with slow-moving apparatus. The increase in daily brushing duration led to a greater reduction of growth, although differences between the species were noted. Aster showed a growth reduction after 20 days of treatment, whereas dusty miller and petunia took longer to respond. Aster and petunia responded significantly even to the shortest daily brushing duration, whereas dusty miller needed 2 hours per day to achieve any significant growth reduction. Increasing the brushing stimulus resulted in injuries to aster leaves in autumn. Brushing with double-layer burlap caused maximum growth reductions in all the species. Brushing most clearly reduced the growth of dusty miller and petunia in autumn, but aster showed similar growth reductions in spring and autumn.
\end{abstract}

Bedding plant seedlings are treated with plant growth regulators, such as butanedioic acid mono(2,2-dimethylhydrazide) (daminozide) and 2-chloro- $N, N, N$-trimethylethanaminium chloride (chlormequat chloride), to meet commercial production standards. Using chemicals, however, increases the risk of pollution. Nonchemical growth-control methods, such as manipulating light quality, imposing daynight temperature differentials (Moe and Heins, 1989), and simulating mechanical stress (MS) (Beyl and Mitchell, 1977), may offer alternatives for growth regulation in bedding plant production. MS reduces elongation in many species (Biddington, 1986; Latimer, 1991). Using MS to control elongation of vegetable seedlings has been studied widely, and MS applied by brushing is recommended for conditioning cauliflower and broccoli (Brassica oleracea L. var. Botrytis Group) seedlings (Biddington and Dearman, 1985; Latimer, 1990). To our knowledge, studies on the responses of bedding plant seedlings to MS are not reported in the literature.

The response to MS may depend on several factors, including MS method (Beyl and Mitchell, 1983; Pöntinen and Voipio, 1992), season (Beyl and Mitchell, 1977; Wurr et al., 1986), and environmental conditions (i.e., Latimer, 1990). Furthermore, species differ in

\footnotetext{
Received for publication 3 Jan. 1994. Accepted for publication 28 July 1994 . The cost of publishing this paper was defrayed in part by the payment of page charges. Under postal regulations, this paper therefore must be hereby marked advertisement solely to indicate this fact.
}

their responsiveness (Baden and Latimer, 1992; Biddington and Dearman, 1985; Pöntinen and Voipio, 1992), and the response may depend on MS duration (Mitchell et al., 1975; Wurr et al., 1986).

Working with crisp lettuce (Lactuca sativa L.), Wurr et al. (1986) found that transplant weight and leaf length were reduced as the duration of MS, applied by brushing, was increased. In this and many other studies, the duration of daily brushing has been short (from $45 \mathrm{sec}$ to $2 \mathrm{~min}$ ), and the number of touches per time unit has been high (40 to 80 per min) (Biddington and Dearman, 1985; Johjima et al., 1992; Pöntinen and Voipio, 1992; Wurr et al., 1986). To our knowledge, studies on brushing in which a low rate of touches per minute is used are not reported in the literature.

Many studies, in which various materials were used to apply MS, have given mixed results, possibly due to the brushing stimulus. For example, a folded sheet of paper affected young vegetable seedlings clearly, but the treatment was insufficient to maintain effective height control in older plants with stronger stems (Baden and Latimer, 1992). The plant response also can vary depending on the 1992).

In the seedling phase, plant species differ from each other in many properties that may interact with responses to MS. For example, stem elongation begins comparatively late in seedlings having a rosette phase. Because bending stems is one of the main prerequisites for elongation reduction (Biddington, 1986), we hypothesize that different types of seedlings need a certain minimum MS stimulus before any response can be expected. type of brushing material (Pöntinen and Voipio,
In our study, the responses of three bedding plant species to varying daily MS treatments (i.e., duration and stimulus of brushing) were examined. The species chosen for the experiments ['Matador Fiery Red' (spring) and 'Miss Nippon' (autumn) aster; 'Diamant' dusty miller; and 'Grandiflora Snow Cloud' petunia] differ from each other in growth habit and leaf toughness.

\section{Materials and Methods}

Two experiments were performed with all three species. The spring experiment concerned the brushing duration and the autumn experiment, the brushing stimulus. In the latter, the responses after the cessation of brushing also were studied.

Brushing was performed with an electric motor-equipped apparatus that moved brushes forward and backward $\left(75 \mathrm{~mm} \cdot \mathrm{s}^{-1}\right)$ above the plants. The length of each pass was $450 \mathrm{~cm}$. The brushes were parked at the ends of benches when not in use. A brush consisted of a rod attached to a frame with burlap (specific weight $270 \mathrm{~g} \cdot \mathrm{m}^{-2}$ ) hung from the rod. Height adjustment was achieved by wrapping the burlap around the rod. As the seedlings grew, the height of the burlap was adjusted so that the seedlings bent at $a n \approx 45^{\circ}$ angle from their erect position at each touch. In autumn, doublelayer burlap was used by attaching burlap to both sides of the rod; triple-layer burlap was used by attaching two layers of burlap to one side and one layer of burlap to the other side of the rod. Burlap layers were not secured together on the brushing side.

In Spring 1992 (28 Apr. to 2 June), the seedlings were brushed with single-layer burlap 60, 120, or 180 times per day. The average interval between brushings was $1 \mathrm{~min}$; therefore, the duration of treatment was 60,120 , or $180 \mathrm{~min} /$ day, respectively. In the first treatment, the number of touches per day was identical to that in the studies of Biddington and Dearman (1985) and Pöntinen and Voipio (1992). In Autumn 1992 (1 Sept. to 7 Oct.), the seedlings were brushed 120 times daily (120 $\mathrm{min}$ ) with single-layer, double-layer, or triplelayer burlap. The first treatment in autumn and the second treatment in spring were identical in stimulus and daily duration. In both experiments, brushing was started at $0800 \mathrm{HR}$. The treatments began 21 to 27 days after emergence, and the treatment period varied from 13 to 38 days (Table 1). The appropriate nonbrushed controls were included in each study, species, and treatment period.

The experiments were performed under ambient light and $\mathrm{CO}_{2}$ conditions in a glasshouse. The mean daily photosynthetically active radiations (PAR) were 25.0 and 11.5 $\mathrm{mol} \cdot \mathrm{m}^{-2}$, the mean daily maxima were 27.3 and $21.3 \mathrm{C}$, and the mean daily minima 17.8 and $16.2 \mathrm{C}$ during the spring and autumn experiments, respectively.

The seedlings were grown in 0.33-liter square pots filled with standard fertilized peat (Finnpeat ST-400B2, Satoturve, Finland). The pots were placed on capillary matting on benches. The plants were irrigated from below 
with water when needed (about every second day) or with a $0.1 \%$ nutrient solution $(14 \mathrm{~N}$, $4.8 \mathrm{P}, 21 \mathrm{~K}, 1.8 \mathrm{~S}, 1.4 \mathrm{Mg}+$ micronutrients) fertilizer ('Puutarhan täyslannos', Kemira, Finland) when needed (about twice a week).

After selected treatment periods (Table 1), 32 plants (eight per replication) were taken for determining shoot fresh weight, shoot dry weight (at $80 \mathrm{C}$ for $24 \mathrm{~h}$ ), plant height (from the cotyledons to the tip of the uppermost leaf), and stem length. Leaf petiole and leaf blade lengths of mature leaves (for leaf counts at maturity see Table 2 , footnote y) were measured for aster. In the results, only the total leaf length is presented because of similar responses in leaf petiole and blade lengths. The number of side shoots (>20 mm long), the length of pedicel in the first flower, and the number of flowers were determined for petunia. Data were subjected to analysis of variance, and separation of means was performed by Student-Newman-Keuls's multiple range test (MSTAT, version 1.2). We did not consider brushing duration a continuous variable because light quality, intensity, temperature, and relative humidity changed during the treatments.

Table 1. Plant age (days after emergence) of aster, dusty miller, and petunia at transplanting, starting of brushing, and the various measurement times.

\begin{tabular}{|c|c|c|c|c|c|c|}
\hline \multirow[b]{3}{*}{ Experiment } & \multicolumn{6}{|c|}{ Plant age (days) } \\
\hline & \multirow[b]{2}{*}{ Species } & \multirow{2}{*}{$\begin{array}{c}\text { Trans- } \\
\text { planting }\end{array}$} & \multirow{2}{*}{$\begin{array}{c}\text { Brushing } \\
\text { started }\end{array}$} & \multicolumn{3}{|c|}{ Measurement ${ }^{2}$} \\
\hline & & & & $1 \mathrm{st}$ & 2nd & 3rd \\
\hline \multirow[t]{3}{*}{ Spring } & Aster & 10 & 21 & $34(13)$ & $41(20)$ & $48(27)^{y}$ \\
\hline & Dusty miller & 10 & 22 & $46(24)$ & $60(38)^{y}$ & \\
\hline & Petunia & 11 & 23 & 42 (19) & $59(36)^{y}$ & \\
\hline \multirow[t]{3}{*}{ Autumn } & Aster & 10 & 21 & $35(14)$ & $42(21)^{y}$ & $56(21)$ \\
\hline & Dusty miller & 17 & 25 & $46(21)^{y}$ & $61(21)$ & \\
\hline & Petunia & 13 & 27 & $41(14)$ & $48(21)^{\mathrm{y}}$ & $62(21)$ \\
\hline
\end{tabular}

${ }^{2}$ Treatment duration (days) in parentheses.

${ }^{y}$ Cessation of brushing.

\section{Results}

Spring. Aster responded significantly to all treatments after 20 days of treatment (Table $2)$. The greatest growth reductions relative to the control were found in shoot fresh and dry weights. As the treatment progressed, the relative growth reductions remained unchanged when plants were brushed for $60 \mathrm{~min} /$ day. With longer daily brushing durations, the relative response increased compared to 20 days treatment. The differences caused by the daily brushing duration were not significant after 13 days of treatment (data not presented), but after 27 days, the longest treatment resulted in the greatest reductions in fresh and dry weights.

After 24 days of treatment, dusty miller was not affected by brushing (data not presented). When the treatment period was 38 days, only the 180-min treatment resulted in reductions in the measured growth variables (Table 2).

Petunia showed no significant responses after 19 days of brushing (data not presented), but after 36 days, all the brushing treatments caused reductions in plant height, stem length, and pedicel length (Table 2). Brushing had no consistent effect on shoot fresh weight but reduced dry weight for 120 and $180 \mathrm{~min}$. At the end of the experiment (plant age 59 days), there was an average of 10 opened flowers per plant. The number of flowers was not affected by brushings (data not presented).

In spring, there were no visible injuries caused by brushing at any sampling time on any species.

Autumn. Brushing caused visible injury to aster leaves. At the cessation of brushing (plant age 42 days), $25 \%$ of aster seedlings brushed with single-layer burlap and all of those treated with double- or triple-layer burlap had torn leaves. Dusty miller and petunia leaves remained uninjured. However, brushing with double- and triple-layer burlap caused some plant loss by breaking the stem close to the root neck. Out of the total number of petunia, aster, and dusty miller plants treated with doublelayer burlap, $7 \%, 1 \%$, and $5 \%$ died, respectively; from those treated with triple-layer burlap, $13 \%, 1 \%$, and $2 \%$ died, respectively.

In autumn, petunia and dusty miller responded more readily to brushing than in spring, but aster showed similar responsiveness in both experiments (Tables 3 and 4).

An increase in brushing stimulus most clearly affected the fresh and dry weights in aster (Fig. 1). The maximum effect was achieved with double-layer burlap. The responses to brushing with double-layer and triple-layer burlap increased as the treatment period progressed. Two weeks after the cessation of brushing, at a plant age of 56 days (Fig. 1, right), the treated plants showed almost the same relative reductions in fresh and dry weight and leaf length as at the end of the treatments. The stem length of brushed plants, however, was either not affected or was even longer than in control plants.

Table 2. Responses (values relative to control in parentheses) of aster, dusty miller, and petunia to daily brushing duration.

\begin{tabular}{|c|c|c|c|c|c|c|c|}
\hline $\begin{array}{l}\text { Treatment } \\
\text { duration (days)/ } \\
\text { plant age (days) }{ }^{z}\end{array}$ & $\begin{array}{c}\text { Daily } \\
\text { brushing } \\
\text { duration (min) }\end{array}$ & $\begin{array}{c}\text { Plant } \\
\text { ht } \\
(\mathrm{mm})\end{array}$ & $\begin{array}{c}\text { Stem } \\
\text { length } \\
(\mathrm{mm})\end{array}$ & $\begin{array}{l}\text { Shoot } \\
\text { fresh } \\
\text { wt (g) }\end{array}$ & $\begin{array}{l}\text { Shoot } \\
\text { dry } \\
\text { wt (g) }\end{array}$ & $\begin{array}{c}\text { Leaf } \\
\text { length } \\
(\mathrm{mm})^{\mathrm{y}}\end{array}$ & $\begin{array}{l}\text { Pedicel } \\
\text { length } \\
(\mathrm{mm})^{\mathrm{x}}\end{array}$ \\
\hline \multicolumn{8}{|l|}{ Aster } \\
\hline \multirow[t]{4}{*}{$20 / 41$} & 0 & 148 a $(100)^{w}$ & $--^{v}$ & 3.5 a (100) & 0.39 a (100) & 128 a $(100)$ & --- \\
\hline & 60 & $136 \mathrm{~b}(92)$ & --- & $2.9 \mathrm{~b}(82)$ & $0.33 \mathrm{bc}(85)$ & $120 \mathrm{~b}(94)$ & --- \\
\hline & 120 & $134 \mathrm{~b}(91)$ & --- & $2.9 \mathrm{~b}(83)$ & $0.35 \mathrm{ab}(90)$ & $116 \mathrm{~b}(91)$ & --- \\
\hline & 180 & $130 \mathrm{~b}(88)$ & --- & $2.5 \mathrm{~b}(71)$ & $0.28 \mathrm{c}(72)$ & 114 b (89) & --- \\
\hline \multirow[t]{4}{*}{$27 / 48$} & 0 & 186 a (100) & $72 \mathrm{a}(100)$ & $7.7 \mathrm{a}(100)$ & $1.10 \mathrm{a}(100)$ & 155 a (100) & --- \\
\hline & 60 & 175 b (94) & $55 \mathrm{~b}(76)$ & $6.8 \mathrm{~b}(89)$ & $0.94 \mathrm{~b}(85)$ & 150 a (97) & --- \\
\hline & 120 & 160 c (86) & $50 \mathrm{~b}(69)$ & $6.0 \mathrm{~b}(78)$ & $0.90 \mathrm{~b}(82)$ & $136 \mathrm{~b}(88)$ & --- \\
\hline & 180 & 159 c (85) & $48 \mathrm{~b}(67)$ & $5.1 \mathrm{c}(66)$ & 0.73 c (66) & $134 \mathrm{~b}(87)$ & --- \\
\hline \multicolumn{8}{|l|}{ Dusty miller } \\
\hline \multirow[t]{4}{*}{$38 / 60$} & 0 & 212 a (100) & 89 a (100) & $21.3 \mathrm{ab}(100)$ & 2.84 a (100) & --- & --- \\
\hline & 60 & 212 a (100) & 89 a (100) & $24.8 \mathrm{a}(116)$ & 2.87 a (101) & --- & -- \\
\hline & 120 & 197 a (93) & $74 \mathrm{~b}(83)$ & $20.9 \mathrm{ab}(98)$ & 2.91 a (102) & --- & --- \\
\hline & 180 & $173 \mathrm{~b}(82)$ & $63 \mathrm{c}(71)$ & $16.1 \mathrm{~b}(76)$ & 2.23 a (79) & --- & --- \\
\hline \multicolumn{8}{|l|}{ Petunia } \\
\hline \multirow[t]{4}{*}{$36 / 59$} & 0 & 203 a (100) & 58.7 a (100) & $5.41 \mathrm{a}(100)$ & 6.8 a (100) & --- & 58 a (100) \\
\hline & 60 & $139 \mathrm{~b}(68)$ & $47.9 \mathrm{~b}(82)$ & $4.48 \mathrm{ab}(83)$ & $6.3 \mathrm{ab}(93)$ & --- & $43 \mathrm{~b}(74)$ \\
\hline & 120 & 126 bc (62) & $42.0 \mathrm{~b}(72)$ & $4.04 \mathrm{~b}(75)$ & $5.8 \mathrm{~b}(85)$ & --- & 37 c (64) \\
\hline & 180 & 114 c (56) & $44.4 \mathrm{~b}(76)$ & $4.32 \mathrm{ab}(80)$ & $5.7 \mathrm{~b}(84)$ & --- & 35 c (60) \\
\hline
\end{tabular}

${ }^{2}$ Length of treatment periods (days)/plant age (days after emergence) at time of treatment cessation.

'Leaf count for aster at different plant ages; fifth and sixth true leaf at 41 and 48 days, respectively.

xFirst flower.

${ }^{\text {wF }}$ or each species and plant age within each column, values followed by the same letter are not significantly different at $P \leq 0.05$.

${ }^{v}$ Variable not measured. 
With dusty miller, double-layer and triplelayer burlap reduced growth more than brushing with single-layer burlap (Fig. 2). Compared to the double-layer burlap, triple-layer burlap did not cause any further reductions. Two weeks after the cessation of the treatments, the differences caused by single-layer burlap almost had disappeared, but the aftereffects of the other treatments were still significant. The plants treated with triple-layer burlap showed the greatest growth reduction.

All the treatments caused significant re- ductions in petunia stem length and shoot fresh and dry weights, but the number of side shoots was not affected (Fig. 3). The maximum reductions were achieved with doublelayer burlap. Two weeks after the cessation of the treatments, the differences among the brushing treatments had disappeared, and the differences between those treated and the control had decreased. When plants were 62 days old, there were 5 to 10 open flowers per plant. Brushing did not affect the number of open flowers or the length of the first flower pedicel (data not presented).

Table 3. Responses (values relative to control in parentheses) of different growth variables to mechanical stress (MS) treatment (brushing with single-layer burlap, 120 brushings per day) in spring and autumn.

\begin{tabular}{|c|c|c|c|c|c|}
\hline \multirow[b]{2}{*}{ Species } & \multirow[b]{2}{*}{ Variable } & \multicolumn{2}{|c|}{ Spring $^{2}$} & \multicolumn{2}{|c|}{ Autumn ${ }^{y}$} \\
\hline & & Control & MS & Control & MS \\
\hline \multirow[t]{4}{*}{ Aster } & Plant ht (mm) & 148 & 134 (91) & 127 & $116(91)$ \\
\hline & Shoot fresh wt (g) & 3.5 & $2.9(83)$ & 4.8 & $4.0(83)$ \\
\hline & Shoot dry wt (g) & 0.39 & $0.35(90)$ & 0.46 & $0.41(89)$ \\
\hline & Leaf length $(\mathrm{mm})$ & 128 & $116(91)$ & 99 & $91(92)$ \\
\hline \multirow[t]{4}{*}{ Dusty miller } & Plant ht (mm) & 129 & $128(99)$ & 29 & $107(83)$ \\
\hline & Shoot fresh wt (g) & 5.6 & $6.1(109)$ & 4.5 & $3.8(84)$ \\
\hline & Shoot dry wt (g) & 0.54 & $0.59(109)$ & 0.36 & $0.30(83)$ \\
\hline & Leaf length (mm) & 109 & $108(99)$ & 109 & $92(84)$ \\
\hline \multirow[t]{3}{*}{ Petunia } & Stem length $(\mathrm{mm})$ & 28 & $34(121)$ & 123 & $83(67)$ \\
\hline & Shoot fresh wt (g) & 7.0 & $8.5(121)$ & 18.2 & $15.4(85)$ \\
\hline & Shoot dry wt (g) & 0.48 & 0.57 (119) & 1.24 & $1.02(82)$ \\
\hline
\end{tabular}

${ }^{2}$ Treatment period 19 to 24 days.

yTreatment period 21 days.

Table 4. Significance of differences in autumn.

\begin{tabular}{|c|c|c|c|c|c|c|}
\hline Species & $\begin{array}{c}\text { Treatment } \\
\text { period (days)/ } \\
\text { plant age (days) }\end{array}$ & $\begin{array}{c}\text { Plant } \\
\text { ht }\end{array}$ & $\begin{array}{r}\text { Stem } \\
\text { length }\end{array}$ & $\begin{array}{c}\text { Shoot } \\
\text { fresh } \\
\text { wt }\end{array}$ & $\begin{array}{c}\text { Shoot } \\
\text { dry } \\
\text { wt }\end{array}$ & $\begin{array}{l}\text { Leaf } \\
\text { length }\end{array}$ \\
\hline \multirow[t]{3}{*}{ Aster } & $14 / 35$ & $* *$ & $---^{y}$ & ** & NS & $* *$ \\
\hline & $21 / 42$ & $* * *$ & --- & $* * *$ & $* * *$ & $* * *$ \\
\hline & $21 / 56$ & --- & $* * *$ & $* * *$ & $* * *$ & $* * *$ \\
\hline \multirow[t]{2}{*}{ Dusty miller } & $21 / 46$ & $* * *$ & --- & $* *$ & $*$ & $* * *$ \\
\hline & $21 / 61$ & $* *$ & $* * *$ & $* *$ & $* * *$ & --- \\
\hline \multirow[t]{3}{*}{ Petunia } & $14 / 41$ & --- & $* * *$ & $*$ & NS & --- \\
\hline & $21 / 48$ & --- & $* * *$ & $* *$ & $* *$ & --- \\
\hline & $21 / 62$ & --- & $* *$ & NS & NS & --- \\
\hline
\end{tabular}

${ }^{2}$ Length of treatment periods (days)/plant age (days after emergence) at time of treatment cessation. ${ }^{\mathrm{y}}$ Variable not measured.

NS, $, * *, * * *$ Nonsignificant or significant at $P \leq 0.05,0.01$, or 0.001 , respectively.

\section{Discussion}

With slow brushing, an increase in the daily brushing duration led to greater reductions in plant growth. The species responded differently, however, and the results were affected by the treatment period and the time of the year.

Different types of seedlings seem to need a certain minimum stress before significant growth reductions are achieved. The required stress for rosette-phase seedlings, as induced by daily brushing, seems to depend on several aspects, including the leaf position and flexibility of the earliest true leaves. If the leaves are erect and flexible, as in aster, the seedling bends easily during brushing. In contrast, when the leaves are more horizontal and stiff, as in petunia and dusty miller, the brush may slide over the plant and cause only a vibration in the seedling until more erect later leaves have grown and stem elongation has started.

Responses may differ depending on the daily stress as varied by brushing duration. It may be inadequate to maintain the reductions at the same level as seedlings grow larger, or the stress may be strong enough to enhance reductions as the treatment period progresses, as was the case with aster at 120 daily brushings. For commercial applications, it is important to know the critical level of daily stress.

As shown by Heuchert and Mitchell (1983) and discussed by Latimer (1991), plant responses to MS vary with the season. In our study, petunia and dusty miller responded more readily in autumn, but aster did not. In autumn, petunia stem elongation started much earlier than in spring, which may explain the difference. The reason for the greater sensitivity of dusty miller in autumn is unclear. Perhaps, the reaction relates to the lower daily PAR and, therefore, diminished dry matter accumulation, which possibly leads to a more tender leaf structure. Aster leaves were injured in autumn by the same treatment that was harmless in spring. Although different cultivars of aster were used in spring and autumn, we assume that the leaves were more tender
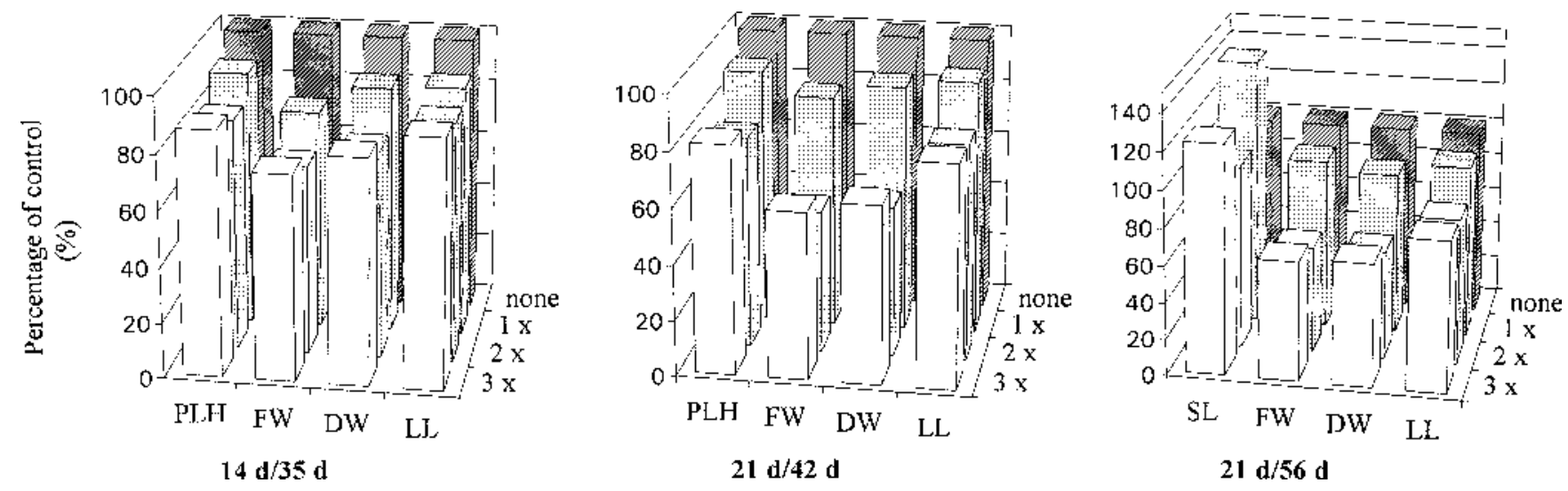

Fig. 1. Responses of aster (percentages of control) to brushing stimulus after various treatment periods at different plant ages at treatment cessation. No brushing (none), brushing with single-layer (1×), double-layer (2×), or triple-layer $(3 \times)$ burlap. PLH = plant height, FW = shoot fresh weight, DW = shoot dry weight, $\mathrm{LL}=$ leaf length, and $\mathrm{SL}=$ stem length. 
late in the season, because other growth variables were virtually unaffected.

In autumn, the double-layer burlap was almost as effective in growth reduction as the triple-layer burlap, probably because two burlap layers were attached to one side and one layer to another side of the rod for the triplelayer brush. The two layers were not secured together and, therefore, bent the stem only once. Thus, the number of touches might have been the same as when brushing with the double-layer burlap, both leading to doublebending. The significance of the number of touches per unit time is one of the many open

questions to be answered before the growth of bedding plant seedlings can be properly controlled by brushing.

\section{Literature Cited}

Baden, S.A. and J.G. Latimer. 1992. An effective system for brushing vegetable transplants for height control. HortTechnology 2:412-413.

Beyl, C.A. and C.A. Mitchell. 1977. Characterization of mechanical stress dwarfing in chrysanthemum. J. Amer. Soc. Hort. Sci. 102:591-594.

Beyl, C.A. and C.A. Mitchell. 1983. Alteration of growth, exudation rate, and endogenous hormone profiles in mechanically dwarfed sun-

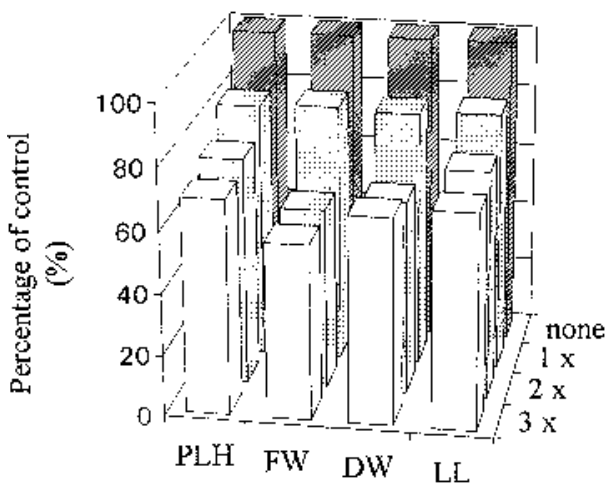

$21 \mathrm{~d} / 46 \mathrm{~d}$

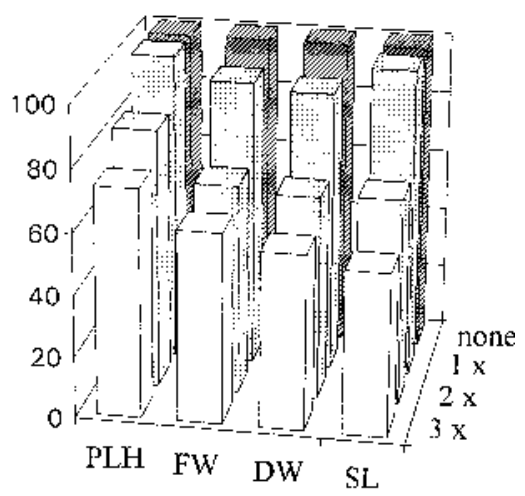

$21 \mathrm{~d} / 61 \mathrm{~d}$

Fig. 2. Responses of dusty miller (percentages of control) to brushing stimulus after different treatment periods at different plant ages at treatment cessation. No brushing (none), brushing with single-layer $(1 \times)$, double-layer $(2 \times)$, or triple-layer $(3 \times)$ burlap. $\mathrm{PLH}=$ plant height, $\mathrm{FW}=$ shoot fresh weight, DW $=$ shoot dry weight, $\mathrm{LL}=$ leaf length, and $\mathrm{SL}=$ stem length.

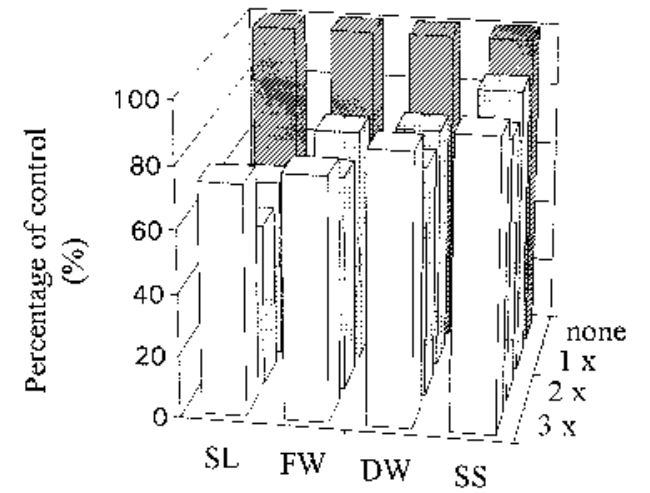

$14 \mathrm{~d} / 41 \mathrm{~d}$

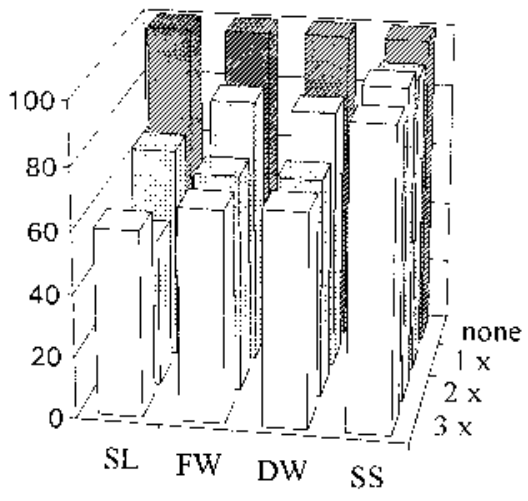

$21 \mathrm{~d} / 48 \mathrm{~d}$ flower. J. Amer. Soc. Hort. Sci. 108:257-262.

Biddington, N.L. 1986. The effects of mechanically-induced stress in plants-A review. Plant Growth Regulat. 4:103-123.

Biddington, N.L. and A.S. Dearman. 1985. The effect of mechanically-induced stress on the growth of cauliflower, lettuce and celery seedlings. Ann. Bot. 55:109-119.

Heuchert, J.C. and C.A. Mitchell. 1983. Inhibition of shoot growth in greenhouse-grown tomato by periodic gyratory shaking. J. Amer. Soc. Hort. Sci. 108:795-800.

Johjima, T., J.G. Latimer, and H. Wakita. 1992. Brushing influences transplant growth and subsequent yield of four cultivars of tomato and their hybrid lines. J. Amer. Soc. Hort. Sci. 117:384-388.

Latimer, J.G. 1990. Drought or mechanical stress affects broccoli transplant growth and establishment but not yield. HortScience 25:1233-1235.

Latimer, J.G. 1991. Mechanical conditioning for control of growth and quality of vegetable transplants. HortScience 26:1456-1461.

Mitchell, C.A., C.J. Severson, J.A. Wott, and P.A. Hammer. 1975. Seismomorphogenic regulation of plant growth. J. Amer. Soc. Hort. Sci. 100:161165.

Moe, R. and R. Heins. 1989. Control of plant morphogenesis and flowering by light quality and temperature. Acta Hort. 272:81-89.

Pöntinen, V. and I. Voipio. 1992. Different methods of mechanical stress in controlling the growth of lettuce and cauliflower seedlings. Acta Agr. Scandinavica, Sect. B, Soil and Plant Sci. 42:246250.

Wurr, D.C.E., J.R. Fellows, and P. Hadley. 1986. The influence of supplementary lighting and mechanically-induced stress during plant raising, on transplant and maturity characteristics of crisp lettuce. J. Hort. Sci. 61:325-330.

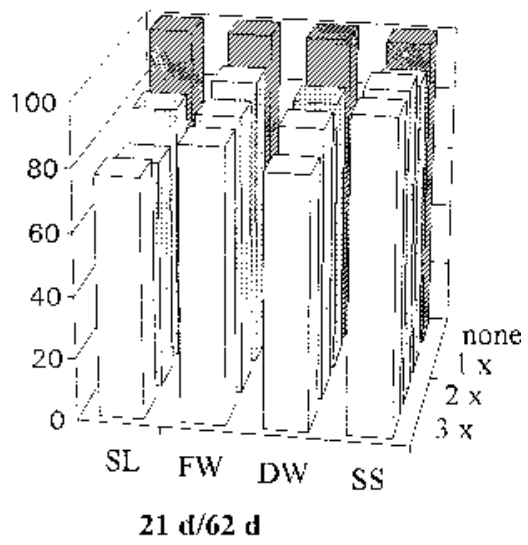

Fig. 3. Responses of petunia (percentages of control) to brushing stimulus after different treatment periods at different plant ages at treatment cessation. No brushing (none), brushing with single-layer ( $1 \times$ ), double-layer $(2 \times)$, or triple-layer $(3 \times)$ burlap. SL = stem length, FW = shoot fresh weight, DW = shoot dry weight, and $\mathrm{SS}=$ number of side shoots. 